\title{
Paideusis
}

\section{Talking to the Animals: Daniel Vokey and Introducing Spirituality into Public Schools}

\section{Dennis Cato}

Volume 14, Number 1, 2001

URI: https://id.erudit.org/iderudit/1072825ar

DOI: https://doi.org/10.7202/1072825ar

See table of contents

Publisher(s)

Canadian Philosophy of Education Society

ISSN

0838-4517 (print)

1916-0348 (digital)

Explore this journal

Cite this document

Cato, D. (2001). Talking to the Animals: Daniel Vokey and Introducing Spirituality into Public Schools. Paideusis, 14(1), 56-60.

https://doi.org/10.7202/1072825ar viewed online.

https://apropos.erudit.org/en/users/policy-on-use/ 


\section{Talking To The Animals: \\ Daniel Vokey and Introducing Spirituality into Public Schools}

\section{Dennis Cato, Lachine, Quebec}

The deep suspicion felt by teachers to the deliverances of educationalists which attempt to prescribe classroom content or practice will come as no suprise to anyone who has spent any time in a secondary school staffroom. While for the most part it may well be misplaced, in the case of Daniel Vokey's "Longing to Connect: Spirituality in Public Schools" (Paideusis, 13:2, 2000), such suspicion is well founded.

According to Vokey, a "growing number of authors" want to introduce spirituality into the curriculum. They are responding "to what they perceive as crises in public education caused at least in part by the exclusion of genuine spirituality from elementary and secondary classrooms."(p.23) The authors believe genuine spirituality "to be universal where religion is particular, and so believe that introducing or reintroducing spirituality into public schools would not compromise liberal principles protecting individual autonomy and cultural diversity." (p.23) Vokey wants to assess the venture's prospects for success under three headings: (a) "What will spirituality offer students and teachers?"; (b) "Obstacles"; and (c) "So What To Do?"

(a) What will spirituality offer students and teachers?

Vokey leaves little doubt as to the benefits of introducing spirituality into public schools. Spirituality will "spark student curiosity" (p.24) and offer them support "to explore the meaning of life and corresponding higher purposes of learning." (p.25) In addition, spirituality in the public schools will invite students to "encounter their 'inner selves' and the interior lives of others in a more open, profound, and caring way than is usually possible in schools."(p26) Finally, spirituality will result in "setting students on a path to the transformed state of consciousness that our very survival as a species requires." (p.27) The "over-arching theme" which embodies the benefits of spirituality is to be found in "connectedness."

Spirituality is typically presented as consisting of, or leading to, student experiences of connectedness with (a) their deepest selves, including all their hopes and fears; (b) other human and non-human souls, in all their similarities and differences;(c) the natural world and the cosmos beyond, in all its awe-inspiring complexity, beauty and mystery; and (d) the larger purposes, potentials, and powers that 
transcend ego's limited concerns. In virtue of its potential to foster these and other connections, spirituality in public schools is presented as the antidote to student indifference towards a fragmented curriculum, their rampant materialism and random vandalism, their callous indifference to social injustice, and their appalling apathy in the face of environmental catastrophe. (p.27)

There can be little doubt. Introducing spirituality into the public schools will have an enormous impact. However, a problem immediately crops up. What is the thing? What does it look like? To simply list the benefits which accrue from its possession is to mistake its effects for its substance, amounting, in effect, to little more than the tautological observation that the possession of health manifests itself in a healthy life-style. Again, for Vokey to say that spirituality "is typically presented as consisting of, or leading to, student experiences of connectedness" is to say either that spirituality is identical to, or the cause of, connectedness but the two claims are mutually exclusive. If spirituality consists of connectedness, then to say that it can lead to it is to assert, incoherently, that something can be its own cause. On the other hand, if spirituality does not consist of connectedness but only leads to it, then some further specification of its substance is required, but Vokey offers none beyond the observation that the growing number of authors see it to be universal where religion is particular. Spirituality must therefore consist of connectedness but what is required for the concept to have any pedagogical purchase - the point of the exercise is, after all, to introduce it into the public schools - is not some list of attributes which accrues from its possession but some account of the activities by which such attributes are to be attained. What would one do to become connected? Do a bit of motorcycle maintenance? Take a walk in the woods? Talk to the animals? Vokey doesn't say.

\section{(b) Obstacles}

One problem with introducing spirituality into the schools is that there is no consensus, no "New World View" to determine what it is. The first thing to realize, Vokey unscientifically asserts without discussion, is that "Scientifically speaking, the mechanistic world view is long out of date."(p.28) The difficulty, however, is not that "there are no alternatives to mechanism and positivism as that there are too many."(p.28) He rejects the first alternative, an "anything-goes-radical-relativism." To leave it up to the students for Vokey would be "to abdicate the educator's responsibility, abandoning students to the perils of the spiritual path, which are legion."(p.28) The criteria for spirituality, rather, (and perhaps oddly in view of that growing number of authors who saw genuine spirituality to be universal where religion is particular) are to be found in "the normative practices of some socially 
and historically conditioned tradition."(p.28) After that, only two alternatives remain, "neither of which is compatible with responsible public schooling in a multicultural context."(p.29) The first incompatible alternative, surprisingly in view of where the criteria of spirituality were to be found, is "to locate the understanding and practice of spirituality squarely within a particular tradition." (p.29) The second incompatible alternative, also suprisingly in view of the fact that spirituality consists of "connectedness," is

to define spirituality so broadly as to buy inclusion at the price of substantive normative content... Defining spirituality in this very general way leaves it unclear how educators could object to students who find meaning and purpose in connectedness with a White Supremacist organization or a Satanic cult.(p.29)

But it doesn't matter. It turns out that spirituality and connectedness are not what public schools are for after all. It is not the absence of consensus on a New World View which constitutes the major obstacle to introducing spirituality into the schools but rather that

the lack of an empirically-supported, philosophically-sound, and cross-culturally accepted new world view is less an obstacle to bringing spirituality into public schools than the lack of accepted procedures to address competing educational priorities based upon conflicting political and economic agendas. Even if we could demonstrate that spiritual education is in the best interests of public school students, that would accomplish little if serving the needs of its students are not what public schools are really for. (p.30)

Those who thought that public schools existed to serve the needs of their students failed to realize that they were really the battleground on which conflicting political and economic agendas clashed by night. They failed to realize that it was not an absence of consensus that was the main obstacle in introducing spirituality and connectedness into the public schools, after all, but rather the lack of accepted procedures to address competing educational priorities. To prove it Vokey states, : "I am not alone in this concern, as the following three quotes attest," (p.30) and yes, he gives three quotes in succession which show that he is not alone and which maintain that there is a crisis in public education since it does not engage the students' need for, well, for spirituality and connectedness.

Vokey's final obstacle to introducing spirituality into the classroom consists of the question, "Who Will Teach the Teachers?" Since the teachers of the teachers are themselves the tainted products of the very institutions in crisis, their instruction can only perpetuate the conditions which preclude the introduction of spirituality into the public schools. According to Vokey, "it is not clear who would educate, or even be qualified to hire, the trustworthy spiritual mentors and guides that even ad hoc 
educational initiatives would require."(p.33) Given the magnitude of the obstacles facing the inclusion of spirituality into public schools, can there be any hope of success? How can consensus on a New World View ever be found? Who will throw off the yoke of those conflicting political and economic agendas and fashion accepted procedures to address those competing educational priorities? Who will teach the teachers?

\section{(c) So What to Do?}

In spite of the fact that the first obstacle to introducing spirituality into the public schools consisted of there being no consensus on the nature and conditions of genuine spiritual development, Vokey's resolution is both swift and bold. What has to be done is to create a consensus. "Proposals to integrate spirituality into public schools," he proclaims, "would benefit from at least some consensus on the nature and conditions of genuine spiritual development and on the forms of education that foster it."(p.33) Having decisively severed the Gordian knot, Vokey next reveals that such consensus will be achieved "through on-going critical dialogue between competing points of view that can both discover and create common ground."(p.33) However, in view of the fact that he rejected mechanism and positivism (it was out of date), an anything-goes-radical-relativism (it abandoned students to the perils of the spiritual path, perils whose number is legion), defining spirituality too narrowly (it was incompatible with responsible public schooling in a multiciltural society) or too broadly (it was to buy inclusion at the price of substantive normative content), one can only wonder as to the prospects of success for discovering and creating that common ground if Vokey is at the table.

In the same vein, Vokey's tackles the second obstacle, that lack of accepted procedures to address competing educational priorities based upon conflicting political and economic agendas, with vigour and determination. Where spirituality is kept out of public schools by those political and economic agendas, what has to be done is for schools to "address the social and political dynamics that keeping it out of the curriculum in the first place. In short, they must direct their attempts to effect change to the cultural chicken as well as to the educational egg." (p.34) While Vokey professes "no expertise in engineering large-scale social change," (p.34) he knows that seizing the cultural chicken is a matter of timing. The moment for Vokey to strike will come when "the gap between word and deed of those competing agendas exceeds some undeterminable limit."(pp.34-5) No wildeyed Jacobin, Vokey will then urge calm, maintaining that "remonstrations and protests should be accompanied by demonstrations that workable alternatives 
exist."(p35) Such remonstrations and demonstrations will come, one supposes, only after that on-going critical dialogue between competing points of view to both discover and create common ground has been adjourned.

In the same way that his resolution of the first two obstacles hindering the inclusion of spirituality into public schools was swift and decisiveness, so now Vokey's resolution of the last obstacle is similarly forthright. In response to the question who would teach the teachers, tainted as they were by those institutions in which spirituality was absent and who had failed as a consequence to attend to their own spiritual development, Vokey is unremitting. "Any adequate response to this issue," he asserts, "would require that those concerned to promote the spiritual development of others, whether inside or outside the schools, attend to their own disciplines of spiritual study and practice."(p.35) But the question of what one is to do when one attends to one's disciplines of spiritual study and practice presupposes a knowledge of that of which spirituality consists, not in terms of some list of attributes which accrues from its possession but rather of some account of the activities by which such attributes are to be attained. What does one do when one attends to one's disciplines of spiritual study and practice? Do a bit of motorcycle maintenance? Take a walk in the woods? Talk to the animals?

Anyone who has spent any time in a secondary school staffroom will not be suprised at the reaction of the teachers when "Longing to Connect" comes sliding under the door. The reason why they will not be surprised is that the teachers' reaction, in this particular case, is entirely justifiable. 